\title{
Usefulness of Serum Brain Natriuretic Peptide as a Predictor Biomarker of Renal Artery Stenosis in Patients with Resistant Hypertension
}

\author{
Sevil UYGUN İLIKKHAN ๑, Muammer BİLICI $\odot \bowtie$ \\ Bulent Ecevit University, Faculty of Medicine, Department of Internal Medicine, Zonguldak, Turkey
}

Cite this article as: Uygun İlikhan S, Bilici M. Usefulness of Serum Brain Natriuretic Peptide as a Predictor Biomarker of Renal Artery Stenosis in Patients with Resistant Hypertension. Türk Diyab Obez 2019;3: 155-163.

\begin{abstract}
Aim: In this study, we aimed to evaluate the relationship between BNP level and RAS in patients with resistant hypertension according to the results of renal arteriography.

Material and Methods: Forty patients with resistant hypertension were included to the study. In order to compare to each other regarding the BNP levels, the patients were evaluated by dividing them into groups as RAS (group1; non-critical (1a) and critical (1b)), non-RAS (group 2), unilateral RAS (non-critical (A) and critical (B)) and bilateral RAS (non-critical (C) and critical (D)) according to the results of renal arteriography.

Results: The serum BNP ( $\mathrm{p}=0.003)$ and serum creatinine $(\mathrm{p}=0.015)$ levels of group $1 \mathrm{~b}$ were also significantly higher than group 1a. The patients in group B had higher serum BNP levels $(\mathrm{p}=0.025)$ and lower creatinine clearance levels ( $\mathrm{p}=0.041)$ compared to group A. Higher serum creatinine $(p=0.006)$, serum BNP levels $(p=0.017)$ and lower creatinine clearance levels $(p=0.049)$ have been observed in group $\mathrm{D}$ compared to group $\mathrm{C}$.

Conclusion: Findings of this study revealed that increased serum BNP levels were significantly associated with the severity of RAS determined by the results of renal arteriography. Thus BNP may be used as a predictive marker to detect the presence of RAS in patients with resistant hypertension.
\end{abstract}

Key Words: Brain natriuretic peptide, Renal artery stenosis, Resistant hypertension

\section{Dirençli Hipertansiyonlu Hastalarda Serum Beyin Natriüretik Peptit Düzeylerinin Renal Arter Stenozunu Öngermede Bir Belirteç Olarak Kullanımı}

\section{ÖZET}

Amaç: Bu çalışmada dirençli hipertansiyon ön tanısıyla selektif renal arteriografisi yapılan ve renal arter stenozu (RAS) saptanan hastalarda serum beyin natriüretik peptit (BNP) düzeyleri ile RAS arasındaki ilişkiyi değerlendirmeyi amaçladık.

Gereç ve Yöntemler: Dirençli hipertansiyonu olan 40 hasta bu çalışmaya alındı. Hastalar renal arter arteriografisi sonucuna göre RAS olan (Grup 1) ve olmayan (Grup 2) olmak üzere iki gruba ayrıldı. Renal arterde darlığ \% 50'den az olanlar Grup 1a, diğerleri Grup 1b olarak kabul edildi. Unilateral non-kritik RAS tespit edilen hastalar Grup A, unilateral kritik RAS tespit edilenler Grup B, bilateral nonkritik RAS tespit edilenler Grup C ve bilateral kritik RAS tespit edilenler Grup D olarak kabul edildi. Hasta grupları BNP düzeyleri açısından karşılaştırıldı.

Bulgular: Grup 1b hastalarda serum BNP ve serum kreatinin değerleri Grup 1a’ya göre daha yüksek saptandı (sırasıyla, p=0,003 ve $\mathrm{p}=0$,015). Grup B hastaları A grubundakilere göre daha yüksek serum BNP düzeyleri ve daha düşük kreatinin klerensine sahiptiler (sırasıyla, $\mathrm{p}=0,025$ ve $\mathrm{p}=0,041$ ). Ayrıca $\mathrm{D}$ grubu hastalar $\mathrm{C}$ grubundakilerle karşılaştırıldığında yüksek serum BNP, kreatinin düzeyleri ve daha düşük kreatinin klerensine sahiptiler(sırasıyla, $\mathrm{p}=0,017, \mathrm{p}=0,006$ ve $\mathrm{p}=0,049$ ).

ORCID: Sevil Uygun İlikhan / 0000-0002-0162-5729, Muammer Bilici / 0000-0002-8678-4605 
Sonuç: Çalışmamızın sonuçlarına göre yüksek serum BNP düzeylerinin renal anjiografi ile belirlenen RAS dereceleri ile anlamlı ilişkisi olduğunu göstermektedir. Bundan dolayı dirençli hipertansiyonu olan hastalarda RAS’ı tahmin etmede serum BNP düzeylerinin bir belirleyici olarak kullanılabilir.

Anahtar Sözcükler: Beyin natriüretik peptit, Renal arter stenozu, Dirençli hipertansiyon

\section{INTRODUCTION}

Renovascular disease (RVD) is a major cause of secondary hypertension that may cause progressive loss of kidney functions and end-stage renal failure (1,2). Renal artery stenosis (RAS) is usually caused by atherosclerosis or fibromuscular dysplasia and also renovascular hypertension is the most common curable cause of high blood pressure (3). Significant renal artery stenosis leads to activation of the renin-angiotensin-aldosterone system and may initiate or exacerbate hypertension, ischemic nephropathy, left ventricular hypertrophy and congestive heart failure (4). The clinical index of suspicion remains paramount in setting the diagnostic strategy (1). There are a number of available tests that can be used to detect RAS including Doppler ultrasound, magnetic resonance angiography (MRA), computed tomography angiography (CTA), renal scintigraphy (i.e. captopril scan), peripheral renin levels, renal vein renin sampling, and selective renal arter angiography. Although conventional selective renal arteryangiography is usually considered the gold standard in confirming the diagnosis of RAS, these tests are based on identifying the functional consequences and the presence of anatomic stenosis of RVD (5).

Brain natriuretic peptide (BNP) is a neurohormone that belongs to the family of natriuretic peptides (6). BNP is synthesized and released mainly from the cardiomyocytes, under genomic control, in response to ventricular wall stretch (7). Elevated levels of BNP which has an approximately 20 minutes of serum half-life, have been shown in chronic renal failure undergoing haemodialysis (8).

The most important physiological effects of BNP are diuresis, natriuresis and arterial vasodilation. These effects depend on inhibition of renin that causes reducing the activity of the renin-angiotensin system. Furthermore, in vitro data have also revealed that angiotensin II directly induces the synthesis and release of BNP. The increased angiotensin II because of the renin-angiotensin-aldosterone system activated via significant RAS, may contribute to increase plasma BNP level (9-11). Experimental studies suggest that the critical stenosis of renal artery more than $70-80 \%$ causes renal parenchymal damage and hypertension. Although the critical ratio of renal artery stenosis is yet unknown, the lesion stenosis over than $50 \%$ of renal artery is recommended as a significant lesion for humans (12).
Nowadays, the plasma BNP level has been used as a biological marker in the diagnosis and treatment of some diseases, especially cardiovascular events (13). Measurement of BNP enable the diagnosis and treatment of theses diseases, and also it may allow to reduce the total cost of management approaches $(6,14)$. Recently, rapid BNP assay is now easily available to physicians in an office, clinic and emergency department.

The aim of this study is to investigate whether plasma levels of BNPs may predict the presence of RAS in patients with resistant hypertension.

\section{MATERIALS and METHODS}

\section{Patient Population}

Seventy-two patients with resistant hypertension and preliminary diagnosis of RAS according to doppler ultrsound results were included to the present study. Resistant hypertension was defined as blood pressure of $140 / 90 \mathrm{~mm} \mathrm{Hg}$ or higher despite the usage of 3 or more medications including one diuretic (15). Thirty-two patients were executed from study according to execution criterias. Selective renal artery angiography was performed to 40 patients (Female/Male: 28/22, mean age: $51.1 \pm 5.6$ ). Physical examination, routine laboratory tests and examinations in terms of end organ damage (echocardiography, 24-hour urine analysis and fundus examination) were performed to all patients.

Patients with resistant hypertension were divided into two groups as RAS (Group 1, n=30) and non-RAS (Group 2, n=10 (that no renal artery stenosis could be detected)) according to the results of selective renal artery angiography. Group 2 was determined as control group. Patients with RAS (Group 1) were also divided into two groups, as Group 1a and Group $1 \mathrm{~b}$, according to the degree of stenosis determined by selective renal artery angiography. Group 1a $(n=13)$ and Group $1 \mathrm{~b}(\mathrm{n}=17)$ were determined as patients with renal artery stenosis less than 50\% (non-critical) and more than $50 \%$ (critical), respectively (12). In addition, patients with RAS were divided into two groups as the unilateral RAS group and the bilateral RAS group. These groups were also divided into two groups as critical and non-critical. Patients with non-critical unilateral RAS were considered as Group A ( $\mathrm{n}=7)$, and patients with critical unilateral RAS 
were considered as Group B ( $\mathrm{n}=12)$. Patients with noncritical bilateral RAS were considered as Group C $(n=6)$, while patients with critical bilateral RAS were considered as Group D ( $\mathrm{n}=5)$. General characteristics of the study group are presented in Table 1.

The study protocol conforms to the ethical guidelines of the 1975 Declaration of Helsinki as reflected in a prioriapproval by our institution's human research committee (the clinical trial registration number: 05.06.2008/08). Informed consent was obtained from all individuals.

\section{Biochemical Analysis}

The patients' blood samples were taken between 08:00 10:00 a.m. after 8 hours of fasting. Urinary creatinine levels were evaluated by Moduler P device (Roche, Tokyo, Japan) using commercial kits of Roche Company. Venous blood samples for BNP were taken into tubes with EDTA and were analyzed in Beckman Coulter Access 2 (Fullerton, CA, USA) device by chemiluminescence method. Creatinine Clearance $(\mathrm{ml} / \mathrm{min})$ was calculated by the formula as follows: Creatinine Clearance $(\mathrm{ml} / \mathrm{minute})=$ urine creatinine $(\mathrm{mg} /$ $\mathrm{dl}) \mathrm{x}$ daily urine volume $(\mathrm{ml}) /$ serum creatinine $(\mathrm{mg} / \mathrm{dl}) \mathrm{x}$ 1440.

\section{Selective Renal Artery Angiography}

Renal angiography was performed with Philips Integris H 5000 cineangiography device. The degree and location of stenosis were calculated by a computer program of the Philips Workstation software. The degree of stenosis of $>$ $50 \%$ was considered as the presence of hemodynamically significant stenosis (12).

\section{Exclusion Criterias}

Patients with acute coronary syndrome and pulmonary embolism history within the last six months, chronic renal failure, heart failure symptoms and / or ejection fraction (EF) $<45 \%$, hemodynamically significant heart valve disease, previously known diabetes mellitus, pregnancy, hypothyroidism, hyperthyroidism, tuberculosis or tuberculosis treatment history, 24-hour urine sodium level more than $100 \mathrm{mEq}$ in terms of monitoring daily sodium intake and history of $\beta$-blockers, angiotensin converting enzyme (ACE) inhibitors and angiotensin receptor blockers (ARB) usage as antihypertensive drugs were excluded from the study. Echocardiographic evaluations were performed by using General Electric Vingmed Vivid FIVE echocardiography device.

\section{Statistical Analysis}

SPSS 19.0 for Windows used for statistical analysis. Categorical variables are given with frequency and percent, while numerical variables are given with mean and standart deviation values. For data analysis, Mann-Whitney U-test and chi-square test were used. Also compliance with

Table 1: Demographics and clinical variables of groups.

\begin{tabular}{lccc}
\hline Characteristic & $\begin{array}{c}\text { Patients (Group1)(n=30) } \\
\text { Mean } \pm \text { Sd }\end{array}$ & $\begin{array}{c}\text { Controls (Group2)(n=10) } \\
\text { Mean } \pm \text { Sd }\end{array}$ & p \\
\hline Age & $51.5 \pm 5.6$ & $50.1 \pm 5.9$ & 0.338 \\
\hline Gender (male/female) & $14 / 16$ & $3 / 7$ & 0.324 \\
\hline Systolic blood pressure $(\mathrm{mmHg})$ & $179.3 \pm 12.1$ & $158 \pm 6.3$ & $<0.001$ \\
\hline Diastolic blood pressure $(\mathrm{mmHg})$ & $104 \pm 8.7$ & $95 \pm 9.7$ & 0.013 \\
\hline Urea $(\mathrm{mg} / \mathrm{dl})$ & $36.6 \pm 9.3$ & $41.1 \pm 6.8$ & 0.094 \\
\hline Creatinine $(\mathrm{mg} / \mathrm{dl})$ & $0.85 \pm 0.2$ & $0.78 \pm 0.1$ & 0.365 \\
\hline Potassium $(\mathrm{mEq} / \mathrm{L})$ & $4.3 \pm 0.3$ & $4.4 \pm 0.3$ & 0.286 \\
\hline Sodium $(\mathrm{mEq} / \mathrm{L})$ & $141.5 \pm 3.4$ & $143.6 \pm 2.9$ & 0.104 \\
\hline Serum BNP $(\mathrm{mg} / \mathrm{dl})$ & $80.5 \pm 30.3$ & $47.2 \pm 10.5$ & $<0.001$ \\
\hline Microalbuminuria $(\mathrm{mg} / 24 \mathrm{~h})$ & $38.8 \pm 47.1$ & $8.8 \pm 4.4$ & 0.033 \\
\hline Microproteinuria $(\mathrm{mg} / 24 \mathrm{~h})$ & $215.9 \pm 178.0$ & $173.9 \pm 110.5$ & 0.901 \\
\hline Creatinine clearance $(\mathrm{ml} / \mathrm{min})$ & $92.4 \pm 17.5$ & $94.5 \pm 11.6$ & 0.272 \\
\hline EF $\%$ & $59.7 \pm 5.5$ & $60.3 \pm 1.8$ & 0.924 \\
\hline LVMI $\left(\mathrm{g} / \mathrm{m}^{2}\right)$ & $165.8 \pm 29.7$ & $152.4 \pm 10.9$ & 0.174 \\
\hline BMI $\left(\mathrm{kg} / \mathrm{m}^{2}\right)$ & $25.7 \pm 1.2$ & $25.4 \pm 1.3$ & 0.509 \\
\hline
\end{tabular}

BNP: Brain natriuretic peptid, EF: Ejection Fraction, Sd: Standard deviation, LVMI: Left ventricular mass index, BMI: Body mass index 
normal distribution was evaluated by Shapiro-Wilk test For all statistical analysis, $\mathrm{p}$ value under 0,05 is assumed as there is a statistical significance.

\section{RESULTS}

Patients with resistant hypertension were divided into two groups as with RAS (Group 1, $\mathrm{n}=30$ ) and non-RAS (Group 2, $\mathrm{n}=10$ ) according to renal arteriography results. Group 2 was determined as the control group. Patients with RAS (Group 1) were also divided into two groups, as group 1a $(n=13)$ and group $1 \mathrm{~b}(\mathrm{n}=17)$, according to the degree of stenosis determined by renal arteriography (renal artery stenosis less than $50 \%$ and more than $50 \%$, respectively). Demographic and clinical characteristics of patients with RAS and nonRAS control group are presented in Table 1 . The systolic $(\mathrm{p}<0.001)$ and diastolic $(\mathrm{p}=0.013)$ blood pressure, serum BNP ( $p<0.001)$, microalbuminuria $(\mathrm{p}=0.033)$ levels of group 1 were significantly higher than group 2 . There was no statistically significant difference in terms of age and gender ( $p>0.05$ ) between control group1 and 2. It was also observed that the serum BNP $(p=0.003)$ and serum creatinine $(p=0.015)$ levels of Group 1b were significantly higher than Group 1a; however, the creatinine clearance levels were significantly lower compared to group $1 \mathrm{a}(\mathrm{p}=0.007)$. The blood pressure measurements were similar in these groups. There were no statistically significant differences between
Group 1a and $1 \mathrm{~b}$ in terms of age and gender distrubition $(\mathrm{p}=0.388, \mathrm{p}=0.133$, respectively) (Table 2$)$.

Patients with RAS were divided into two groups as unilateral and bilateral stenosis. These groups were also divided into two groups as critical and non-critical. Patients with unilateral non-critical and critical RAS were considered as group A $(n=7)$ and group $B(n=12)$ respectively. Patients with bilateral non-critical and critical RAS were considered as group $C(n=6)$ and group $D(n=5)$ respectively. The patients in group B had higher serum BNP levels $(p=0.025)$ and lower creatinine clearance levels $(p=0.041)$ compared to group A. Higher serum creatinine $(\mathrm{p}=0.006)$ and serum BNP levels $(\mathrm{p}=0.017)$ as well as lower creatinine clearance levels $(\mathrm{p}=0.049)$ have been detected in group $\mathrm{D}$ when compared to Group C (Table 3).

The ocular fundus findings occured due to resistant hypertension in patients with RAS and non-RAS were detected. There were significant differences between patients with grade 1 and grade 2 hypertensive retinopathy $(\mathrm{HR})$ in terms of sistolic $(\mathrm{p}=0.003)$ and diastolic $(\mathrm{p}=0.049)$ blood pressure, serum creatinine $(\mathrm{p}=0.008)$, serum BNP ( $\mathrm{p}=0.009)$, microalbuminuria $(\mathrm{p}=0.013)$ and microproteinuria $(\mathrm{p}=0.027)$ levels; however, the ceratinine clearance $(p=0.057)$ levels were statistically lower in patients with grade $1 \mathrm{HR}$ than with grade $2 \mathrm{HR}$ (Table 4 ).

Table 2: The comparison of groups among patients with RAS according to severity of RAS.

\begin{tabular}{lccc}
\hline \multicolumn{1}{c}{ Characteristic } & $\begin{array}{c}\text { Group Ia (Non-critical RAS) } \mathbf{n = 1 3} \\
\text { Mean } \pm \text { Sd }\end{array}$ & $\begin{array}{c}\text { Group Ib (Critical RAS) } \mathbf{n}=\mathbf{1 7} \\
\text { Mean } \pm \text { Sd }\end{array}$ & p \\
\hline Age & $50.3 \pm 5.5$ & $52.4 \pm 5.7$ & 0.388 \\
\hline Gender (male/female) & $4 / 9$ & $10 / 7$ & 0.133 \\
\hline Systolic blood pressure $(\mathrm{mmHg})$ & $179.2 \pm 14.4$ & $179.4 \pm 10.4$ & 0.863 \\
\hline Diastolic blood pressure $(\mathrm{mmHg})$ & $103.1 \pm 9.5$ & $105.0 \pm 8.2$ & 0.667 \\
\hline Urea $(\mathrm{mg} / \mathrm{dl})$ & $34.5 \pm 9.2$ & $38.2 \pm 9.4$ & 0.357 \\
\hline Creatinine $(\mathrm{mg} / \mathrm{dl})$ & $0.75 \pm 0.1$ & $0.9 \pm 0.2$ & 0.015 \\
\hline Potassium $(\mathrm{mEq} / \mathrm{L})$ & $4.3 \pm 0.3$ & $4.4 \pm 0.4$ & 0.900 \\
\hline Sodium $(\mathrm{mEq} / \mathrm{L})$ & $141.5 \pm 3.5$ & $141.6 \pm 3.5$ & 0.782 \\
\hline Serum BNP $(\mathrm{mg} / \mathrm{dl})$ & $63.1 \pm 14.1$ & $93.8 \pm 32.8$ & 0.003 \\
\hline Microalbuminuria $(\mathrm{mg} / 24 \mathrm{~h})$ & $51.8 \pm 64.15$ & $28.8 \pm 26.2$ & 0.753 \\
\hline Microproteinuria $(\mathrm{mg} / 24 \mathrm{~h})$ & $269.9 \pm 221.7$ & $174.5 \pm 128.7$ & 0.286 \\
\hline Creatinine clearance $(\mathrm{ml} / \mathrm{min})$ & $102.8 \pm 18.9$ & $84.4 \pm 11.5$ & 0.007 \\
\hline EF $\%$ & $59.3 \pm 4.9$ & $60.4 \pm 6.0$ & 0.537 \\
\hline LVMI $\left(\mathrm{g} / \mathrm{m}^{2}\right)$ & $165.8 \pm 29.2$ & $165.8 \pm 30.9$ & 0.983 \\
\hline BMI $\left(\mathrm{kg} / \mathrm{m}^{2}\right)$ & $25.7 \pm 0.8$ & $25.7 \pm 1.4$ & 0.770 \\
\hline
\end{tabular}

BNP: Brain natriuretic peptid, EF: Ejection Fraction, Sd: Standard deviation, LVMI: Left ventricular mass index, BMI: Body mass index 
Table 3: The comparison of groups with non-critical and critical stenosis in patients with unilateral or bilateral RAS.

\begin{tabular}{|c|c|c|c|c|c|c|}
\hline & \multicolumn{2}{|c|}{ Unilateral RAS } & \multirow[b]{2}{*}{$\mathbf{p}$} & \multicolumn{2}{|c|}{ Bilateal RAS } & \multirow[b]{2}{*}{$\mathbf{p}$} \\
\hline & $\begin{array}{l}\text { Noncritical } \\
(A)(n=7) \\
\text { Mean } \pm \text { Sd }\end{array}$ & $\begin{array}{c}\text { Critical } \\
(B)(n=12) \\
\text { Mean } \pm \text { Sd }\end{array}$ & & $\begin{array}{c}\text { Noncritical } \\
(C)(n=6) \\
\text { Mean } \pm \text { Sd }\end{array}$ & $\begin{array}{c}\text { Critical } \\
(\mathrm{D})(\mathrm{n}=5) \\
\text { Mean } \pm \mathrm{sd}\end{array}$ & \\
\hline Age & $48.6 \pm 6.7$ & $54.0 \pm 5.9$ & 0.108 & $52.2 \pm 3.2$ & $48.6 \pm 2.8$ & 0.085 \\
\hline Gender (male/female) & $2 / 5$ & $7 / 5$ & 0.223 & $2 / 4$ & $3 / 2$ & 0.399 \\
\hline Systolic blood pressure (mmHg) & $171.4 \pm 14.6$ & $176.7 \pm 10.9$ & 0.409 & $188.3 \pm 7.5$ & $186.0 \pm 5.5$ & 0.609 \\
\hline Diastolic blood pressure (mmHg) & $98.5 \pm 10.6$ & $103.7 \pm 9.3$ & 0.271 & $108.3 \pm 4.0$ & $108.0 \pm 4.5$ & 0.892 \\
\hline Urea $(\mathrm{mg} / \mathrm{dl})$ & $31.8 \pm 10.4$ & $39.3 \pm 10.5$ & 0.150 & $37.5 \pm 7.3$ & $34.8 \pm 5.3$ & 0.714 \\
\hline Creatinine (mg/dl) & $0.7 \pm 0.07$ & $0.8 \pm 0.2$ & 0.226 & $0.8 \pm 0.1$ & $1.1 \pm 0.1$ & 0.006 \\
\hline Potassium (mEq/L) & $4.4 \pm 0.3$ & $4.3 \pm 0.3$ & 0.467 & $4.3 \pm 0.4$ & $4.6 \pm 0.4$ & 0.463 \\
\hline Sodium $(\mathrm{mEq} / \mathrm{L})$ & $140.6 \pm 3.1$ & $141.6 \pm 3.4$ & 0.385 & $142.5 \pm 3.9$ & $141.8 \pm 4.4$ & 0.854 \\
\hline Serum BNP (mg/dl) & $58.3 \pm 12.6$ & $94.7 \pm 39.2$ & 0.025 & $68.6 \pm 14.8$ & $92.0 \pm 9.7$ & 0.017 \\
\hline Microalbuminuria (mg/24h) & $29.4 \pm 32.4$ & $26.8 \pm 27.1$ & 0.999 & $78.0 \pm 84.2$ & $33.6 \pm 26.1$ & 0.647 \\
\hline Microproteinuria (mg/24h) & $174.3 \pm 156.9$ & $184.7 \pm 149.9$ & 0.899 & $381.5 \pm 245.1$ & $150.2 \pm 57.6$ & 0.201 \\
\hline Creatinine clearance (ml/min) & $106.7 \pm 23.2$ & $85.9 \pm 12.4$ & 0.041 & $98.1 \pm 13.1$ & $80.8 \pm 9.1$ & 0.049 \\
\hline $\mathrm{EF} \%$ & $61.3 \pm 4.3$ & $59.7 \pm 7.2$ & 0.764 & $57.0 \pm 4.7$ & $60.8 \pm 1.0$ & 0.111 \\
\hline LVMI $\left(\mathrm{g} / \mathrm{m}^{2}\right)$ & $160.1 \pm 28.05$ & $160.8 \pm 25.5$ & 0.472 & $172.5 \pm 31.8$ & $177.8 \pm 42.3$ & 0.784 \\
\hline BMI $\left(\mathrm{kg} / \mathrm{m}^{2}\right)$ & $25.7 \pm 0.7$ & $25.7 \pm 1.4$ & 0.579 & $25.7 \pm 1.03$ & $25.6 \pm 1.7$ & 0.867 \\
\hline
\end{tabular}

BNP: Brain natriuretic peptid, EF: Ejection Fraction, Sd: Standard deviation, LVMI: Left ventricular mass index, BMI: Body mass index

Table 4: Characteristics of patients with HTRP (Grade I-II).

\begin{tabular}{lccc}
\hline Variables & $\begin{array}{c}\text { HTRP Grade I }(\mathbf{n}=\mathbf{1 9}) \\
\text { Mean } \pm \text { Sd }\end{array}$ & $\begin{array}{c}\text { HTRP Grade II }(\mathbf{n}=\mathbf{2 1}) \\
\text { Mean } \pm \text { Sd }\end{array}$ & p \\
\hline Age & $51.3 \pm 5.4$ & $51.0 \pm 5.9$ & 0.946 \\
\hline Gender $(\mathrm{male} / \mathrm{female})$ & $7 / 12$ & $10 / 11$ & 0.497 \\
\hline Systolic blood pressure $(\mathrm{mmHg})$ & $167.1 \pm 13$ & $180.2 \pm 12.7$ & 0.004 \\
\hline Diastolic blood pressure $(\mathrm{mmHg})$ & $98.4 \pm 10.6$ & $105 \pm 7.7$ & 0.049 \\
\hline Urea $(\mathrm{mg} / \mathrm{dl})$ & $38.0 \pm 9.2$ & $37.4 \pm 8.9$ & 0.957 \\
\hline Creatinine $(\mathrm{mg} / \mathrm{dl})$ & $0.7 \pm 0.1$ & $0.9 \pm 0.2$ & 0.008 \\
\hline Potassium $(\mathrm{mEq} / \mathrm{L})$ & $4.3 \pm 0.3$ & $4.4 \pm 0.4$ & 0.946 \\
\hline Sodium $(\mathrm{mEq} / \mathrm{L})$ & $142.9 \pm 3.4$ & $141.3 \pm 3.3$ & 0.203 \\
\hline Serum BNP $(\mathrm{mg} / \mathrm{dl})$ & $59.1 \pm 19.7$ & $84.0 \pm 33.7$ & 0.009 \\
\hline Microalbuminuria $(\mathrm{mg} / 24 \mathrm{~h})$ & $14.05 \pm 16.1$ & $46.9 \pm 52.8$ & 0.013 \\
\hline Microproteinuria $(\mathrm{mg} / 24 \mathrm{~h})$ & $147.8 \pm 107.1$ & $257.4 \pm 188.8$ & 0.027 \\
\hline Creatinine clearance $(\mathrm{ml} / \mathrm{min})$ & $97.8 \pm 17.6$ & $88.5 \pm 13.7$ & 0.057 \\
\hline EF $\%$ & $60.3 \pm 5.5$ & $59.4 \pm 4.2$ & 0.226 \\
\hline LVMI $\left(\mathrm{g} / \mathrm{m}^{2}\right)$ & $25.7 \pm 0.9$ & $25.6 \pm 1.4$ & 0.122 \\
\hline
\end{tabular}

HTRP: Hypertensive Retinopathy, Sd: Standard deviation, BNP: Brain natriuretic peptid, EF: Ejection Fraction, LVMI: Left ventricular mass index, BMI: Body mass index 


\section{DISCUSSION}

There are limited numbers of studies evaluating the relationship between serum BNP levels and RAS in the literature. RAS is a curable cause of renovascular hypertansion. Untreated RAS is usually resulting in progressive loss of kidney functions and end-stage renal failure. Moreover 10-40\% of end-stage renal failures develop from RAS $(16,17)$. Due to the control effect of RAAS blocking agents on blood pressure, most of the patients with RAS remain asymptomatic until the development of end-stage renal failure. The gold standard diagnostic method of RAS is selective renal artery angiography $(18,19)$. It is invasive and nefrotoxic. Additionally, kidney functional tests do not provide sufficient data for the diagnosis of RAS. Thus, biochemical markers are needed for early diagnosis of RAS, because early diagnosis may reduce the rate of mortality, morbidity, the need of dialysis and also the treatment costs of uncontrolled hypertension.

BNP is from natriuretic peptide group and plays an important role in renal physiology. The main source of circulating BNP is ventricular myocardial tissue; however, BNP synthesis and release have been shown in glomerular mesangial and epithelial cells (20). Left ventricular wall stress and volume load stimulate BNP secretion. Increased heart rate, endothelin I and especially AT II, can also induce serum BNP synthesis (21). BNP increases due to RAAS in patients with renovascular hypertension $(10,11,22)$. Reasons that narrow renal artery lumen increase AT II levels by activating RAAS. Moreover, it has been reported that increased serum BNP levels decrease when AT I receptor blocker losartan was used (9). For patients who were suspected to have bilateral RAS, beta-blockers, ACE inhibitors or ARBs were not used. Therefore, patients have got no AT II inhibition. To the findings of comparisons between RAS patients and patients without stenosis revealed that RAS patients had significantly higher BNP levels. This significance occured even in patients with stenosis less than $50 \%$. In our study, the increased BNP levels in patients with RAS might have occured due to stimulation of serum BNP release by increased AT II in the stenotic renal artery. We have detected a significant elevation in each case between the groups in terms of serum BNP. Although significant elevations between groups in terms of blood pressure were detected, there were no significant difference between patients with less than 50\% stenosis and patients with more than $50 \%$ stenosis. Despite the lack of difference in blood pressure levels between the two groups, higher levels of serum BNP emerged as a remarkable finding. According to these findings, we think that serum BNP level evaluation in patients with uncontrolled hypertension may be helpful for early diagnosis of RAS. In their study, Muussalo et al. compared patients with renovascular hypertension to patients with moderate and to patients with severe hypertensive. They reported significantly higher levels of serum BNP and ANP in patients with RAS (23). Twelve patients with renal artery stenosis more than 50\% were included in their study. They compared 37 patients with severe hypertension to 29 patients with moderate hypertension. In the study they reported $58 \%$ sensitivity and $90 \%$ specificity of serum BNP level in detecting RAS. However, they stated that they had few patients with RAS in the report. They found that sistolic and diastolic blood pressures were higher in RAS patient group. These results correlate with our findings. Although there was a difference between patients with severe hypertension and patients with moderate hypertension in terms of sistolic and diastolic pressure levels, there was no significant difference between these groups in terms of BNP levels. Although there was no significant difference between critical stenosis group (Group 1b) and non-critical stenosis group (Group 1a) in terms of blood pressure levels, we found a significant difference in terms of BNP levels. We think that this allows us to exclude the impact of increased blood pressure on serum BNP level elevation due to ventricular wall stretch and hypertrophy. There are studies indicating the relationship between serum BNP levels and left ventricular mass in the literature (24). In our study, serum BNP levels and left ventricular mass index were not different among groups and they did not show any correlation between each other. The present study revealed that there was no impact of BNP elevation due to the stress of the ventricle. Silvia et al. found a decrease on serum BNP levels after renal revascularization in patients with RAS (25). In that study, it was reported that serum BNP levels were higher in $81 \%$ of the patients. They have achieved a decrease in BNP levels after revascularization with stents in these patients. In our study, we found higher levels of BNP in patients with more than $50 \%$ stenosis than patients with less than 50\% stenosis. In their study, Silvia et al. accepted BNP levels more than $80 \mathrm{pg} / \mathrm{ml}$ as high and they reported that these patients benefited from revascularization (25). In the present study, $15 \%$ of the patients had non-critical stenosis and $85 \%$ of the patients had critical bilateral or unilateral stenosis, when patients with BNP levels more than $80 \mathrm{pg} / \mathrm{ml}$ were considered.

In an experimental study that evaluated RVD doublekidney one-clip model of left ventricular BNP levels, it was shown that BNP levels increased 6 hours after renal artery clamping, and remained high during 4 days after renal artery clamping (26). However, this model did not provide enough information about long-term BNP levels 
due to the short-term nature of the experiment. In another study, it was reported that increased BNP levels decreased to previous levels when double-kidney one-clip model was performed (22).

In the literature, there are conflicting studies regarding the effect of BNP on GFR. In their study conducted on 213 predialysis patients, Vickery et al. found a strong correlation between BNP and GFR (27). They reported that each $10 \mathrm{~mL}$ / min decrease of GFR resulted in 20.6\% increase of BNP levels and $37.7 \%$ increase of NT-proBNP levels. However, Tagore et al. reported that N-terminal-proBNP levels were determined by left ventricular hypertrophy, hemoglobin and GFR while BNP levels remained unaffected (28). In their study conducted for investigating the roles of kidney, natriuretic peptide clearance (NPR-C) receptor and protease digestion in elimination of synthetic human BNP in rabbit plasma, Almirez et al. reported 1.5 times decrease in BNP elimination between the bilateral renal artery ligated group and control group. This shows that kidney is rich of NP-C receptor and protease (possibly NEP 24.11) and has a role in BNP metabolism (29). There are data suggesting that kidneys play a significant role in the removal of the BNP in humans. In a study conducted in 1993 by Richards et al. in which regional plasma levels of endogenous BNP in patients with cardiac disease were monitored, it was found a significant arteriovenous concentration gradient between femoral artery and renal vein which was a sign of the role of kidney on BNP removal (29). Schou et al. reported that both BNP and NT-proBNP were excreted by the kidneys (30). Khan et al. reported a strong correlation between BNP, NT-proBNP and GFR and an increase in serum BNP levels as chronic renal failure progresses (31). Tanemoto et al. published their study conducted to investigate the determinants of undiagnosed RAS on 202 Japanese patients with atherosclerosis risk. They used MRI in the diagnosis of RAS and considered atherosclerotic RAS as stenosis more than $50 \%$. Patients with $0-50 \%$ stenosis were included in the control group. In their study, serum creatinine levels and creatinine clearance were identified as determinants of RAS (32). In our study, selective renal angiography, which is a gold standard for the detection of RAS, was used. The results showed that the patients with significant stenosis had elevated serum BNP levels and decreased creatinine clearance. This decrease in clearance was observed especially in patients with Group $1 \mathrm{~b}$ (which is more than $50 \%$ stenosis), and both in patients with unilateral critical stenosis and bilateral critical stenosis.

In some studies serum creatinine, microproteinuria and microalbuminuria was shown as determinants of RAS in patients who underwent angiography (33). The decrease of creatinine clearance is more rapid in microalbuminuric hypertensive patients (34). Furthermore, these patients have increased frequency of cardiovascular events. In our study, we found a significantly higher level of microalbuminuria in patients with RAS. We found that this difference was especially originated from patients with more than $50 \%$ stenosis.

In our study, we found a significantly higher serum BNP levels in patients with grade $2 \mathrm{HR}$. While dividing the patients into groups, it was not considered whether the patients had RAS or not. Although it is reported that BNP elevates more in macrovascular complications, there was no study evaluating BNP levels in patients with HR. The recent studies have been mostly conducted on diabetic patients. Published in the year 2002, in their study conducted on diabetic patients (those with macroalbuminuria and cardiac pathology were excluded), Asakawa et al. did not report a significant difference between patients with or without retinopathy in terms of serum BNP levels (35). In their study conducted on 223 diabetic patients, Igarashi et al. reported higher levels of BNP in patients with hypertension, coronary artery disease, retinopathy, nephropathy, and macroalbuminuria (36). Diabetic patients were not included in our study. It can be concluded that due to the increase in the degree of retinopathy and parallel kidney damage, the serum BNP levels increase.

In the literature there was not sufficient number of study investigating the relationship between serum BNP levels and RAS in humans. In this study, we aimed to evaluate whether or not there was a correlation between serum BNP levels and degree of RAS in patients who underwent renal arteriography due to RAS suspicion that resulted as RAS diagnosis. As a result, the findings of the present study suggest that serum BNP levels can be used as a determinant of RAS. Evaluation of BNP levels in patients with uncontrolled hypertension may lead the way for further studies.

We have focused on early detection of RAS using a noninvasive and available biochemical marker. Nowadays, the plasma BNP level has been used as a biological marker in the diagnosis and treatment of some diseases, especially for cardiovascular events (13). Measurement of BNP level may enable the early diagnosis and treatment of these diseases. Thus, it may allow to reduce the total cost of the management approaches $(6,14)$. Recently, rapid BNP assay is now easily available to physicians in an office, clinic and emergency department. Findings of the present study presented that increased serum BNP levels were significantly associated with the severity of RAS determined by renal arteriography so BNP may be used as a predictive marker to detect presence of RAS in patients with resistant hypertension. 


\section{REFERENCES}

1. Bloch MJ, Basile J. The diagnosis and management of renovascular disease: A primary care perspective. Part I. Making the diagnosis.J Clin Hypertens. 2003;5(3):210-218.

2. Bloch MJ, Basile J. Clinical insights into the diagnosis and management of renovascular disease. An evidence-based review. Minerva Med. 2004;95(5):357-373.

3. Zeller T. Percutaneous endovascular therapy of renal artery stenosis: Technical and clinical developments in the past decade. J Endovasc Ther. 2004;11(2):96-106.

4. Dubel GJ, Murphy TP. The role of percutaneous revascularization for renal artery stenosis. Vasc Med. 2008;13(2):141-156.

5. Bloch MJ: An evidence-based approach to diagnosing renovascular hypertension. Curr Cardiol Rep. 2001;3(6):477484.

6. Safley DM, McCullough PA: The emerging role of brain natriuretic peptide in the management of acute and chronic heart failure in outpatients. Heart Fail Monit. 2003;4(1):13-20.

7. Miasel AS. B-type natriüretic peptid (BNP) leves: Diagnonostic and therapeutic potential. Rev Cardiovasc Med. 2001;2:13-8.

8. Jensen KT, Carstens J, Ivarsen P, Pedersen EB. A new, fast and reliable radioimmunassay of brain natriüretic peptide in human plasma. Reference values in healty subjects and in patients with different diseases. Scand J Clin Lab Invest. 1997; 57: 529-540.

9. Wiese S, Breyer T, Dragu A, Wakili R, Burkard T, SchmidtSchweda S, Füchtbauer EM, Dohrmann U,Beyersdorf F, Radicke D, Holubarsch CJ. Gene expression of brain natriuretic peptide in isolated atrial and ventricular myocardium: Influence of angiotensin II and diastolic fiber length. Circulation. 2000;102:3074-3079.

10. Martinez-Maldonado M. Pathophysiology of renovascular hypertension. Hypertension. 1991;17:707-719.

11. Nishimura M, Milsted A, Bloch $\mathrm{CH}$, Brosnihan KB, Ferrario $\mathrm{CM}$. Tissue renin-angiotensin systems in renal hypertension. Hypertension. 1992;20:158-167.

12. Klassen PS, Svetkey LP. Diagnosis and managment of renovascular hypertension. Cardiology in Review. 2000;8(1):17-29.

13. Duygu H, Türk U, Zoghi M, Nalbantgil S. The Importance of plasma B-type natriuretic peptide levels in cardiovascular diseases. Anadolu Kardiyol Derg. 2005;5:305-311.

14. Tsutamoto T, Horie M. Brain natriuretic peptide. Rinsho Byori. 2004;52(8):655-668.

15. From British Hypertension Society Technique of blood pressure measurment recommended by the British Hypertension Society. J Hypertens. 1985;3:293.

16. Preston RA, Epstein M. Ischemic renal disease: An emerging cause of chronic renal failure and end stage renal disease. J Hypertens. 1997;15:1365-1377.
17. van Ampting JM, Penne EL, Beek FJ, Koomans HA, Boer WH, Beutler JJ. Prevalence ofatherosclerotic renal artery stenosis in patients starting dialysis. Nephrol Dial Transplant. 2003; 18(6):1147-1151

18. Safian RD, Textor SC. Renal-artery stenosis. N Eng J Med. 2001;344:431-442.

19. Wright JR, Shurrab AE, Cheung C, Waldek S, O’Donoghue DJ, Foley RN, Mamtora H, Kalra PA. A prospective study of determinants of renal functional outcome and in mortality atherosclerotic renovascular disease. Am J Kidney Dis. 2002;39:1153-1161

20. Lai KN, Leung JC, Yandle TG, Fisher S, Nicholls MG. Gene expression and synthesis of natriüretic peptides by kultured human glomeruler cells. J Hypertens. 1999;17: 575-583.

21. Davidson NC, Naas AA, Hanson JK. Comparison of atriyal natriuretic peptide, $\mathrm{BNP}$ and $\mathrm{N}$-terminal proatriyal natriuretic peptide indicators of left ventricular systolic dysfunction. Am J Cardiol. 1996;77:828-831.

22. DeForrest JM, Knappenberger RC, Antonaccio MJ, Ferrone RA, Creekmore JS. Angiotensin II is a necessary component for the development of hypertension in the two kidney, one clip rat. Am J Cardiol. 1982;49:1511-1517.

23. Mussalo H, Vanninen E, Ikäheimo R, Hartikainen. NTproANP and BNP inrenovascular and in severe and mild essential hypertension. Kidney Blood Pres Res. 2003;26:34-41.

24. Bettencourt P, Ferreira A, Sousa T, Ribeiro L, Brandão F, Polónia J, Cerqueira-Gomes M, Martins L. Brain natriuretic peptide as a marker of cardiac involvement in hypertension. Int J Cardiol. 1999;69(2):169-177.

25. Silva JA, Chan AW, White CJ, Collins TJ, Jenkins JS, Reilly JP, Ramee SR. Elevated brain natriuretic peptide predicts blood pressure response after stent revascularization in patients with renal artery stenosis. Circulation. 2005 25;111(3):328-333.

26. Kurtz WK, Pfeifer M, Hochel K, Riegger GA, Kramer BK. Different regulation of left ventricular ANP, BNP and adrenomodullin mRNA in the two-kidney, one-clip model of renovascular hypertension. Pflugers Arch. 2001;442:212-217.

27. Vickery S, Price CP, John RI, Abbas NA, Webb MC, Kempson $\mathrm{ME}$, Lamb EJ. B-type natriuretic peptide (BNP) and aminoterminal proBNP in patients with CKD: Relationship to renal function and left ventricular hypertophy. Am J Kidney Dis. 2005;46(4):610-620.

28. Tagore R, Ling LH, Yang H, Daw HY, Chan YH, Sethi SK. Natriuretic peptides in chronic kidney disease. Clin J Am Soc Nephrol. 2008; 3(6):1644-1651.

29. Almirez R, Protter AA. Clearance of human brain natriuretic peptide in rabbits; Effect of the kidney, the natriuretic peptide clearance receptor, and peptidase activity. J Pharmacol Exp Ther. 1999;289(2):976-980.

30. Schou M, Dalsgaard MK, Clemmesen O, Dawson EA, Yoshiga CC, Nielsen HB, Gustafsson F, Hildebrandt PR, Secher NH. Kidney extract BNP in healty young men. Physiol. 2005;99:1676-1680. 
31. Khan IA, Fink J, Nass C, Chen H, Christenson R, deFilippi CR. N-terminal pro-B-type natriuretic peptide for identifying coronary artery disease and left ventricular hypertrophy in ambulatory chronic kidney disease patients. Am J Cardiol. 2006;97:1530-1534.

32. Tanemoto M, Saitoh H, Satoh F, Satoh H, Abe T, Ito S. Predictors of undiagnosed renal artery stenosis among Japanese patients with risk factors of ateroscklerosis. Hypertens Res. 2005;28:237-242.

33. Park S, Jung JH, Seo HS, Ko YG, Choi D, Jang Y, Chung N, Cho SY, Shim WH. The prevalence and clinical predictors of atherosclerotic renal artery stenosis in patients undergoing coronary angiography. Heart Vessels. 2004;19:275-279.
34. Bianchi S, Bigazzi R, Campese VM. Microalbuminuria in essential hypertension. J Nephrol. 1997;10(4): 216-219.

35. Asakawa H, Fukui T, Tokunaga K, Kawakami F. Plasma brain natriuretic peptide levels in normotensive Type 2 diabetic patients without cardiac disease and macroalbuminuria. J Diabetes Complications. 2002;16(3):209-213.

36. Igarashi M, Jimbu Y, Hirata A, Tominaga M. Characterization of plazma brain natriuretic peptide level in patients with type 2 diabetes. Endocr J. 2005;52(3): 353-362. 
